\title{
Karst within the Confining unit of the Floridan Aquifer: A Geophysical Investigation
}

\author{
Can Denizman ${ }^{1} \&$ Donald M. Thieme ${ }^{1}$ \\ ${ }^{1}$ Valdosta State University, Department of Physics, Astronomy, and Geosciences, Valdosta, Georgia, USA \\ Correspondence: Can Denizman, Valdosta State University, Department of Physics, Astronomy, and Geosciences, \\ Valdosta, GA 31698, USA. E-mail: Tel: 1-229-249-2744. E-mail: cdenizma@valdosta.edu
}

Received: July 22, 2018

Accepted: July 24, $2018 \quad$ Online Published: August 11, 2018

doi:10.5539/jgg.v10n3p12

URL: http://dx.doi.org/10.5539/jgg.v10n3p12

\begin{abstract}
Occurrences of surficial karstic depressions in south-central Georgia are generally attributed to the dissolution within the Floridan aquifer even though it is overlain by a confining unit of varying thickness. This study explores the karst development within the carbonate layers of the confining unit using geophysical investigation techniques, namely electrical resistivity tomography (ERT), and ground penetrating radar (GPR). Surveys at sites of observed surficial depressions reveal shallow karst development which is unrelated to the deeper karst processes within the Floridan aquifer. The overlying unit, generally comprised of impermeable siliciclastic sediments, appears to have lower degrees of confinement at sites of increased karst development where carbonate layers are present. This has important implications not only for structural stability of the area, but also for the environmental sensitivity of the Floridan aquifer.
\end{abstract}

Keywords: electrical resistivity tomography (ERT), ground penetrating radar (GPR), karst, Floridan aquifer

\section{Introduction}

Karst terrain presents many unique challenges for hydrology, engineering, and environmental management. The identification and exploration of subsurface cavities and groundwater conduits in karst provides significant information for understanding and managing many geohazards, including doline ("sinkhole") formation, slope failure, flooding, and groundwater pollution. Detailed information about subsurface conditions are essential to groundwater exploration and extraction, land use planning, construction project design, and other sorts of land management in karst terrain (Tolmachev, 2007; Tolmachev \& Leonenko, 2011; Upchurch \& Littlefield, 1988; Waltham \& Fookes, 2003).

Traditional methods of geologic mapping and subsurface investigation yield much information for identifying the lithologic and structural conditions where we find karst and karst aquifers (Florea, 2006; Florea, Budd, \& Hyatt, Wilson, Givens, \& Jacobs, 2001; Parise \& Pascali, 2003; Upchurch \& Littlefield, 1988). Detailed threedimensional models derived from geophysical techniques are proving to be essential, however, for many of the practical problem of karst terrain. Ground-penetrating radar (GPR) and Electrical Resistivity Tomography (ERT) are two widely used techniques which now provide relatively detailed three-dimensional models for hydrogeological studies (Sawyer, Zhu, Currens, Atcher, \& Binley, 2005; Siriex, Riss, Rey, Prétou, \& Lastennet, 2014) as well as subsurface karst explorations (Farooq et al, 2012; Gutierrez et al, 2018; Kruse, Grasmueck, Weiss, \& Viggiano, 2006; Makarov, Modin, Pelevin, Skobelev, \& Efremov, 2017; Nouiova et al. 2013; Park et al, 2014; Redhaouina, Ilondo, Gabtni, Sami, \& Bedir, 2016).

We report here our results of investigations responding to a number of requests from local residents and land managers in south Georgia, USA. Most of these case studies involve homeowners concerned about surficial depressions in their properties and/or structural damage in their residences. We have utilized both GPR and ERT techniques to investigate the subsurface geology. Due to the clay-rich shallow horizons in the area, GPR has not always provided high resolution and deep penetration. However, much more conclusive subsurface imagery obtained by ERT suggests a widespread karst development in the confining unit of the Floridan aquifer, which has important implications not only for the structural integrity of the terrain, but also for the groundwater quality.

\section{Geologic and Hydrogeologic Setting}

The study area for the research reported here is in the Coastal Plain physiographic province in south-central 
Georgia, USA (Figure 1). The topographic features of the area include low, gently rolling hills dissected by a welldeveloped drainage network. Elevation ranges from approximately $12 \mathrm{~m}$ above sea level in stream valleys to $80 \mathrm{~m}$ in the highlands. The karst features include many dolines, doline lakes, disappearing streams, and wetlands connected through the subsurface to one of the most prolific karst aquifers in the world, the Floridan aquifer. The Floridan aquifer is hosted within a thick sequence of Tertiary rocks deposited on the Florida carbonate platform (Bellino, Kuniansky, O’Reilly, \& Dixon, 2018; McConnell \& Hacke, 1993; Miller, 1986; Williams \& Kuniansky, 2015). Bedding plane and fracture-controlled dissolution within the thick layers of carbonate rocks has produced well-developed cave and conduit systems, providing high transmisivity and storativity conditions in a threedimensional karst framework.

In south-central Georgia and northern Florida, the carbonate rocks which host the Floridan aquifer are overlain by siliciclastic deposits of sand and clay assigned to the Hawthorn Group (Bellino, Kuniansky, O'Reilly, \& Dixon, 2018; Huddlestun, 1988, 1997; McConnell \& Hacke, 1993; Miller, 1986; Williams \& Kuniansky, 2015). The Upper Miocene Hawthorn Group rocks also include thin carbonate layers of dolomite and limestone (Huddlestun, 1988, 1997; Miller 1986). While most of the confinement is due to the clay and clay rich sand layers, in many cases, impermeability is significantly compromised by the dissolution of carbonate layers within the confining layer. In other words, as shown in this study, there is karst development in the confining unit that overlies the Floridan aquifer. This makes the aquifer susceptible to severe contamination risks through discrete recharge points by disappearing streams or by stormwater runoff (Denizman \& Parrish, 2017).

While potable water is found in limited amounts within "shallow" aquifers in the Hawthorn Group and other Tertiary or Quaternary rocks, the underlying Floridan aquifer is the primary water source for Valdosta and the surrounding area (McConnell \& Hacke, 1993). Artesian conditions characterize the Floridan aquifer here, primarily because of its confinement by varying thickness of the Hawthorn Group sediments (McConnell \& Hacke, 1993; Stringfield \& LeGrand 1966; Upchurch \& Lawrence 1984). The confinement is breached, however, by collapse and subsidence sinkholes as well as by the channel of the Withlacoochee River, the erosional base level for the major drainage network in the area. The Withlacoochee River flows from north to south, and in many places is in direct hydraulic contact with the Floridan aquifer. Depending on the relative elevations of the river stage and the hydraulic head of the Floridan aquifer, the river may lose water to the aquifer or be recharged by springs along its path. One important potential application for three-dimensional models of the sort developed here will be to provide details about these areas and paths of interaction between surface water and groundwater.

\section{Methods and Materials}

The electrical resistivity (ER) technique is based on determining the electrical resistivity values of subsurface material by inducing an electrical current on the ground surface and measuring the potential differences. Resistivity measurements vary with the type of geologic material as well as the fluids in the interstitial or conduit porosity. Its significantly improved version, Electrical Resistivity Tomography (ERT) technique, involves an automatic switching of a large number of electrodes located along a line for acquiring profiling data. The images, also known as apparent resistivity pseudo sections, are processed by inversion software to obtain interpreted resistivity crosssections of the subsurface (Bernard, Leite, \& Vermeersch, 2005).

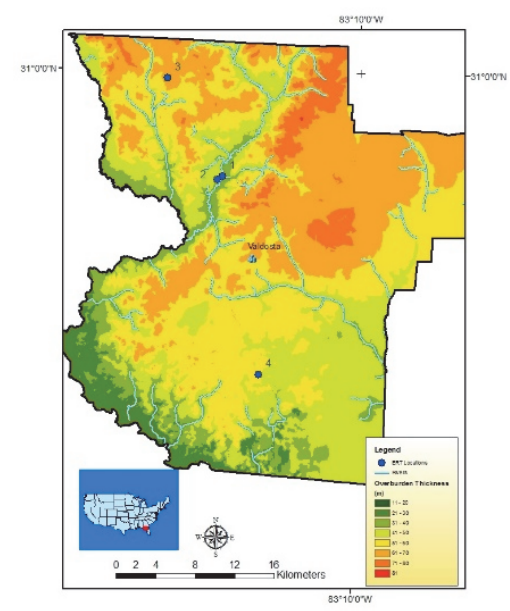

Figure 1. Study area and the thickness of the confining unit above the Floridan aquifer. Thickness values were calculated by a GIS interpolation of borehole data provided by McConnell and Hacke, 1993 
In this study ERT data were obtained by Advanced Geosciences, Inc. Superstring R8 Resistivity Meter. This is an eight-channel instrument with eight receivers where for each current injection the electric potential between nine electrodes can be measured simultaneously (AGI, 2015). Four different sites were surveyed using dipole-dipole array with electrode spacings ranging from 1 to $3 \mathrm{~m}$ (Figure 1). In each run, contact tests were performed and electrodes with high contact resistivity were excluded from data processing. The data were processed by the Smooth Model Inversion method using the AGI EarthImager 2-D inversion software.

Information about the subsurface is also acquired by a GPR system. This technique involves emitting highfrequency electromagnetic waves, recording the variations in the reflected signals by a receiving antenna (Denizman, Brevik, \& Doolittle, 2010). In this study, a MÅLA GPR system with an X3M controlling unit and a $100 \mathrm{MHz}$ antenna was used. Major constraint for the use of GPR in this study was the high electrical resistivity geologic materials such as clay-rich sediments encountered at all sites except Site 2.

\section{Results}

Site 1 is located in an active karst area known as the Withlacoochee Sink (Figure 1). Here, during low potentiometric level conditions, a small creek that split off the Withlacoochee River disappears into a series of doline and cave systems (Figure 2). While this site has the lowest thickness of the confining unit overlying the Floridan aquifer $(\sim 35 \mathrm{~m})$, ERT profiles above a known cave, a swallet where the creek disappears, show very shallow ( 1 m deep) dry cavities with high resistivity values $(\sim 19,000 \mathrm{ohm}-\mathrm{m})$, with a deeper cave system saturated with fresh groundwater (Figure 3). Karst development, albeit very close to the top of the Floridan aquifer, occurs above the aquifer, within the carbonates of the confining unit.

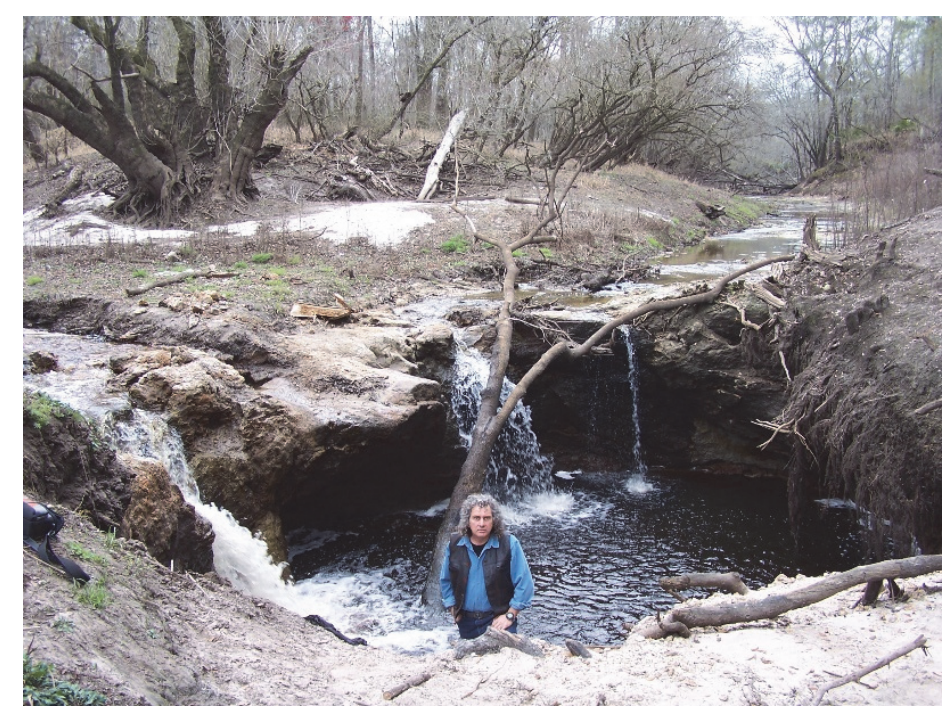

Figure 2. A disappearing stream in a newly-opened sinkhole at Site 1

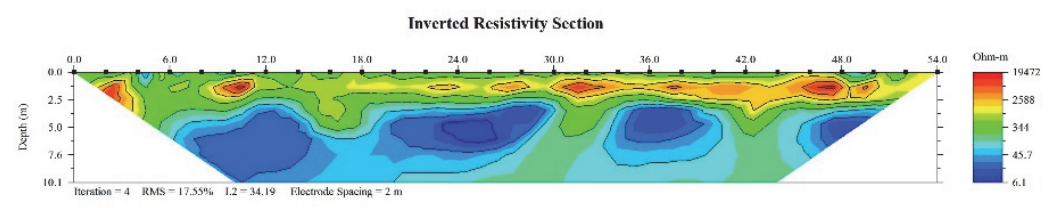

Figure 3. ERT profile at Site 1

Site 2 is located in the backyard of a house near Withlacoochee Sink area. Upon being contacted by the resident of the property, who reported structural damage in the house and apparent depressions in the back yard, we conducted both GPR and ERT surveys of the property. The site has a very similar geologic make up with an overburden thickness of approximately $35 \mathrm{~m}$. The ERT clearly shows at least three shallow dry partially air-filled cavities (Figure 4). High resistivity values that extend from 38 to $43 \mathrm{~m}$ in the survey line align next to a partially collapsed pool, verifying a karst-related structural failure. Lower resistivity layers underlying the cavities are interpreted as clay-rich zones of the confining unit. These anomalies match with the disturbances in the GPR 
profile. Down-warping reflectors in the profile suggest depressions located in the bedrock whereas black zones are likely to indicate possible cavities.

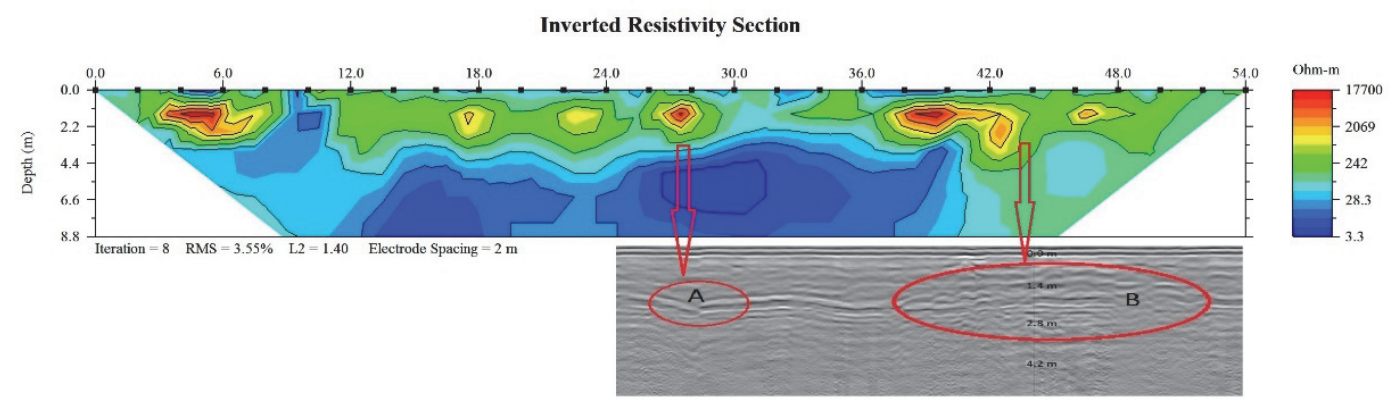

Figure 4. ERT and GPR profile at Site 2

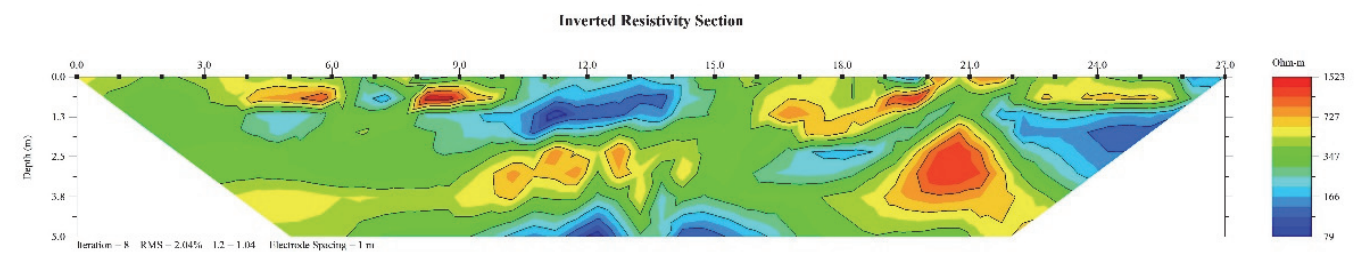

Figure 5. ERT profile at Site 3

\section{Inverted Resistivity Image}

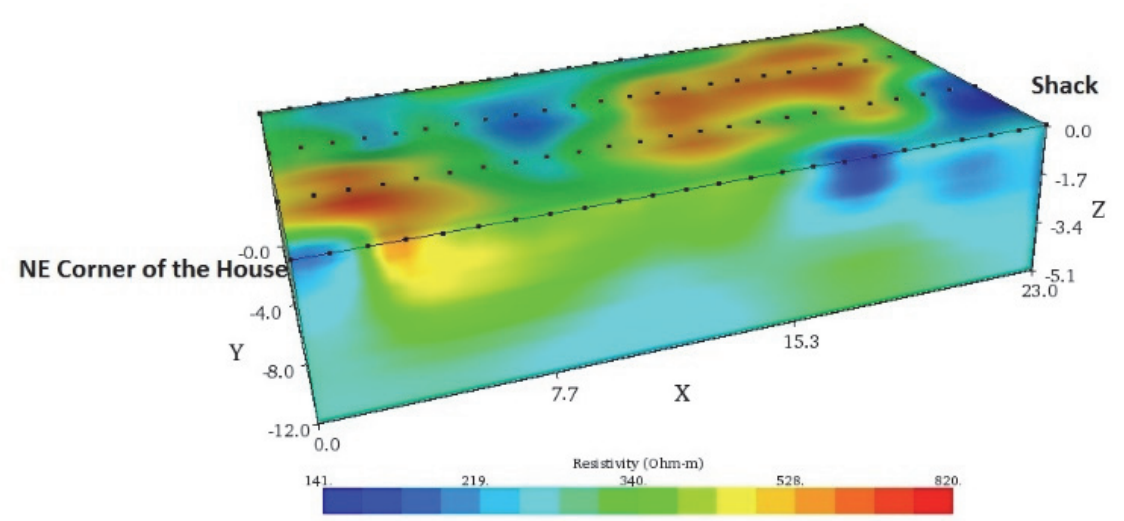

Figure 6. Three-dimensional ERT diagram for Site 3 


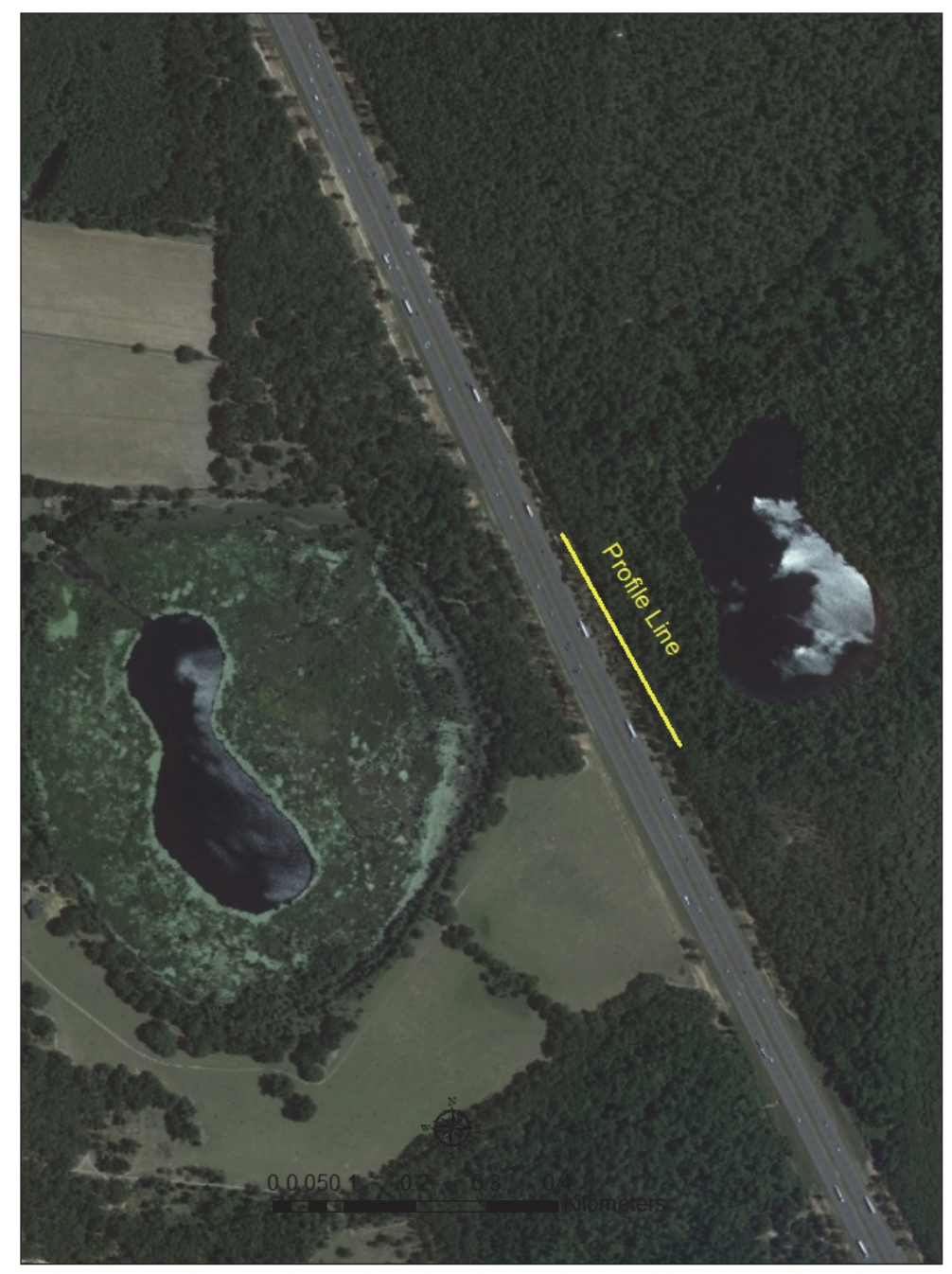

Figure 7. Aerial view of Site 4

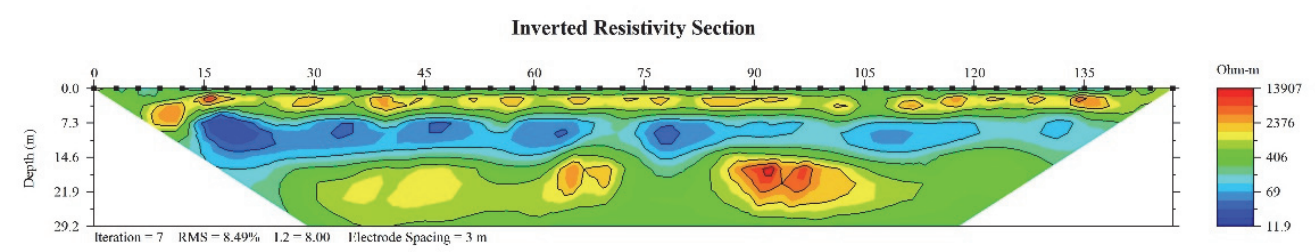

Figure 8. ERT profile at Site $4(0-147 \mathrm{~m})$

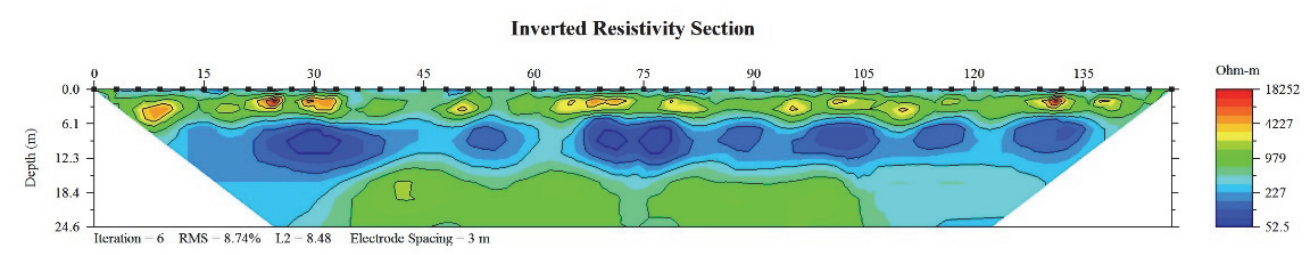

Figure 9. ERT profile at Site $4(147-249 \mathrm{~m})$ 
Located in the northern part of the study area, Site 3 has an elevation of $70 \mathrm{~m}$ above sea level. Here, the thickness of the confining unit is approximately $65 \mathrm{~m}$, and the carbonate rocks of the Floridan aquifer lie too deep to form karstic depressions on the surface. Nevertheless, when called upon by a property owner who observed areas of surface subsidence, we ran a number of GPR and ERT profiles at this site. Almost all survey lines show pockets of high resistivity zones, indicated as shades of yellow to red in the ER profiles (Figure 5), that may be interpreted as air-filled cavities within the carbonate bearing zones of the Hawthorn Group lithologies. Moreover, there is also a deeper ( 2.5 to 5 meter deep) zone of cavity development that could be seen in the profile. As expected from the field inspections there is an extended cavity development towards the northeastern corner of the house (Figure 6).

With an elevation of $60 \mathrm{~m}$ above sea level, Site 4 is located between two doline lakes suspected to be connected by a karst conduit system (Figure 7). In an attempt to explore a possible connection between these two karst features, expected to be originating from the Floridan aquifer, we ran two ERT surveys with a total length of 294 (Figures 8 and 9). Apparently, the three meter electrode spacing we used in our exploration was too short to provide us with the required depth to reach the Floridan aquifer, located approximately $52 \mathrm{~m}$ below the surface. Nevertheless, we detected significant shallow and medium-depth karst development separated by a clay-rich low conductivity horizon within the confining unit.

\section{Discussion}

Results of geophysical investigation at four sites in south Georgia, USA demonstrate development of karst dissolution within Hawthorn Group rocks which form the confining unit for the Floridan aquifer. Resistivity crosssections show subsurface voids or cavities at all four sites. Cavities which are air-filled and characterized by relatively high resistivity predominate beneath the more "upland" settings such as Site 3, in the northern part of the study area. Even at more low-lying settings such as Sites 1 and 2, however, where the Floridan aquifer lies only about $35 \mathrm{~m}$ below the ground surface, cavities have been identified within these Hawthorn Group rocks.

Dolines and other karst features in northern Florida and south Georgia are typically described in previous research as resulting from collapse or subsidence of the confining layer above areas of limestone dissolution within the Floridan aquifer (Hyatt, Wilson, Givens, \& Jacobs, 2001; Miller, 1986; McConnell \& Hacke, 1993; Stringfield \& LeGrand 1966; Upchurch \& Lawrence 1984). For example, Miller (1986) describes solution features as developing in the Floridan aquifer rather than from the dissolution of carbonate layers within the upper confining unit. Similarly, McConnell and Hacke (1993) explain the underground sinking of the Withlacoochee River near Sites 1 and 2 as the result of limestone dissolution in the underlying Floridan aquifer. While there is extensive karst development in the aquifer, this study shows many underground cavities and depressional features in the area are caused by a much more shallow process, an epikarst development within the carbonate layers of Hawthorn Group rocks. This process, depending on the thickness of the confining unit, reduces the degree of confinement, and renders the Floridan aquifer vulnerable to contamination even where it is considered isolated from surficial stresses.

The Floridan aquifer, like other karst aquifers, is highly susceptible to contamination that originates from surficial processes. Its direct connection to the surface via solutional features, such as dolines and swallets, means that little or no natural remediation occurs for contaminants entering the aquifer. Rapid groundwater flow through enlarged cavities and conduits within the aquifer results in complicated contaminant plumes that cannot be accurately modeled with conventional modeling techniques developed for Darcian flow in homogeneous and isotropic media (Hartman, Goldscheider, Wagener, Lange, \& Weiler, 2014). Detailed three dimensional models are needed, and those can be based in part upon geophysical results of the sort presented here (Redhaounia et al., 2016; Sawyer et. al., 2005; Sirieix et al., 2014). The results presented here demonstrate the ability of ERT to identify and distinguish both air-filled and water-filled cavities in the subsurface. Migration of surface water into local aquifer bodies as well as other changes in potentiometric surfaces and groundwater chemistry can be modeled in future research.

In many parts of south Georgia and north Florida, the risk of contamination to the Floridan aquifer is low because of the thickness and lithological properties of the confining Hawthorn Group rocks. However, karst development in the confining layer, as shown in this study, has important implications not only for structural stability of the area, but also for the environmental sensitivity of the Floridan aquifer. Dolines, commonly formed during prolonged droughts or heavy rainfall events, provide direct access to the aquifer, posing great risk of groundwater contamination. As Parise, Closson, Gutierrez, \& Stevanovic (2015) state, management in the karst environment is critical due to its unique properties such as direct interaction between subsurface and surface environments and the ground instability related to subsurface karst development. Environmental and engineering problems caused by karst geohazards such as sinkholes, floods, slope movements, and groundwater pollution indicate the importance of sustainable approaches and integrated planning in developing projects in karst terrain (Guo, Jiang, Yuan, \& Polk 2013; Parise, 2015; Zini, Calligaris, \& Franco, 2015). As suggested by Tolmachev (2007), 
government regulations are often needed. Regulation is difficult, however, when the karst terrain spans more than one political unit with subtle changes in geology. That is the case for the terrain studied here where the geology changes subtly from Florida to Georgia above an underlying karst aquifer.

\section{References}

AGI (Advanced Geosciences, Inc,), (2015). SuperSting Earth Resistivity, IP \& SP System with Wi-Fi® Instruction Manual. Vol. 3. Austin, TX.

Bellino, J. C., Kuniansky, E. L., O’Reilly, A. M., \& Dixon, J. F. (2018). Hydrogeologic setting, conceptual groundwater flow system, and hydrologic conditions 1995-2010 in Florida and Parts of Georgia, Alabama, and South Carolina. Scientific Investigations Report 2018-5030, U.S. Geological Survey, Reston, VA. https://doi.org/10.3133/sir20185030

Bernard, J., Leite, O., \& Vermeersch, F. (2006). Multi-electrode resistivity imaging for environmental and mining applications. IRIRS Instrument, Orleans, France.

Denizman, C., \& Parrish, E., (2017). Assessment of a pipeline route in a karst terrain, Florida, USA. Journal of Remote Sensing \& GIS, 6(3). https://doi.org/10.4172/2469-4134.1000210

Denizman, C., Brevik, C. E., \& Doolittle, J. (2010). Ground-Penetrating Radar (GPR) investigation of a rapidly developed island-like feature in a lake in southern Georgia, USA. Journal of Cave and Karst Studies, 72(2), 94-99. https://doi.org/10.4311/jcks2008es0060

Farooq, M., Park, S., Young, S. S., Kim, J. H., Mohammad, T., \& Adepelumi, A. (2012). Subsurface cavity detection in a karst environment using electrical resistivity (er): A case study from Yongweol-ri, South Korea. Geosci Res J., 16(1), 75-82.

Florea, L. J. (2006). Architecture of air-filled caves within the karst of the Brooksville Ridge, west-central Florida. J. Cave Karst Studies, 68(2), 64-75.

Florea, L. J., Budd, D., \& Brinkmann, R. (2009). Caves and Karst of West-Central Florida. In: Palmer, AN, Palmer, MV (eds) Caves and Karst of the USA. National Speleological Society, Huntsville, AL, 189-196.

Guo, F., Jiang, G., Yuan, D., \& Polk, J. S. (2013). Evolution of major environmental geological problems in karst areas of Southwestern China. Environ. Earth Sci., 69, 2427-2435. https://doi.org/10.1007/s12665-012-20708

Gutierrez, F., Zarroca, M., Linares, R., Rogue, C., Carbonel, D., Guerrero, J., McCalpin, J. P., Comas, X., \& Cooper, A. H. (2018). Identifying the boundaries of sinkholes and subsidence areas via trenching and establishing setback distances. Engineering Geology, 233(2018), 255-268. https://doi.org/10.1016/j.enggeo.2017.12.015

Hartmann, A., Goldscheider, N., Wagener, T., Lange, J., \& Weiler, M. (2014). Karst water resources in a changing world: Review of hydrological modelling approaches. Rev. Geophys, 52, 218-242. https://doi.org/10.1002/2013RG000443

Huddlestun, O. F. (1988). A revision of the lithostratigraphic units of the Coastal Plain of Georgia - Miocene through Holocene. Bulletin 104, Georgia Geologic Survey, Atlanta.

Huddlestun, O. F. (1997). Geologic Atlas of the Valdosta Area. Geologic Atlas 10, Georgia Geologic Survey, Atlanta.

Hyatt, J. A., Wilson, R., Givens, J. S., \& Jacobs, P. (2001). Topographic, geologic, and hydrogeologic controls on dimensions and locations of sinkholes in thick covered karst, Lowndes County, Georgia. In: Beck, BF, Herring, JG, Geotechnical and Environmental Applications of Karst Geology and Hydrology. A.A. Balkema, Lisse, pp. 39-45.

Kruse, S., Grasmueck, M., Weiss, M., \& Viggiano, D. (2006). Sinkhole structure imaging in covered Karst terrain. Geophys Res. Lett., 33, L16405. https://doi.org/10.1029/2006GL026975

Makarov, D. V., Modin, I. N., Pelevin, A. A., Skobelev, A. D., \& Efremov, K. D. (2017). Application of ERT to Identify Buried Crossover Karst Features in the Design of Linear Constructions. Paper presented at EAGE, $23^{\text {rd }}$ European Meeting of Environmental and Engineering Geophysics, Near Surface Geoscience '17, Malmo, Sweden.

McConnell, J. B., \& Hacke, C. M. (1993). Hydrogeology, water quality, and water-resources development potential of the Upper Floridan Aquifer in the Valdosta area, south-central Georgia. USGS Water-Resources Investigation Report 93-4044, 44p. 
Miller, J. A. (1986). Hydrogeologic framework of the Floridan aquifer system in Florida and in parts of Georgia, South Carolina, and Alabama. U.S. Geological Survey Professional Paper 1403-B, p. 91.

Nouioua, I., Rouabhia, A., Fehdi, C., Boukelloul, M.L., Gadri, L., Chabou, D., \& Mouici, R. (2013). The application of GPR and electrical resistivity tomography as useful tools in detection of sinkholes in the Cheria Basin (northeast of Algeria). Environ Earth Sci., 68, 1661-1672. https://doi.org/10.1007/s12665-012-1859-9

Parise M., Closson, D., Gutierrez, F., \& Stevanovic, Z. (2015). Anticipating and managing engineering problems in the complex karst environment. Environ. Earth Sci., 74, 7823-7835. https://doi.org/10.1007/s12665-0154647-5

Parise, M. (2015). Karst geohazards: Causal factors and management issues. Acta Carsologica 44/3, 401-414. https://doi.org/10.3986/ac.v44i3.1891

Parise, M., \& Pascali, V. (2003). Surface and subsurface environmental degradation in the karst of Apulia (southern Italy). Environ Geol., 44, 247-256. https://doi.org/10.1007/s00254-003-0773-6

Park, M. K., Park, S., Yi, M. J., Kim, C., Son, J. S., Kim, J. H., \& Abraham, A. A. (2014). Application of electrical resistivity tomography (ERT) technique to detect underground cavities in a karst area of South Korea. Environ Earth Sci., 71, 2797-2806. https://doi.org/10.1007/s12665-017-7112-9

Redhaounia, B., Ilondo, B. O., Gabtni, H., Sami, K., \& Bedir, M. (2016). Electrical Resistivity Tomography (ERT) Applied to Karst Carbonate Aquifers: Case Study from Amdoun, Northwestern Tunisia. Pure Appl. Geophys, 173, 1289-1303. https://doi.org/10.1007/s00024-015-1173-z

Sawyer, A. H., Zhu, J., Currens, J. C., Atcher, C., \& Binley, A. (2005). Time-lapse electrical resistivity imaging of solute transport in a karst conduit. Hydrol. Process, 29, 4968-4976. https://doi.org/10.1002/hyp.10622

Sirieix, C., Riss, J., Rey, F., Prétou, F., \& Lastennet, R. (2014). Electrical resistivity tomography to characterize a karstic Vauclusian spring: Fontaine d'Orbe (Pyrénées, France). Hydrogeology Journal, 22, 911-924. https://doi.org/10.1007/s10040-013-1095-8

Stringfield, V. T., \& LeGrand, H. E. (1966). Hydrology of limestone terranes in the Coastal Plain of the Southeastern United States. Geological Society of America Special Papers, 93, 1-46. https://doi.org/10.1130/SPE93-p1

Tolmachev, V. (2007). Issues of environmental impacts of karst in standards on construction in Russia. Environ. Geol., 51, 787-790. https://doi.org/10.1007/s00254-006-0396-9

Tolmachev, V., \& Leonenko, M. (2011). Experience in collapse risk assessment of building on covered karst landscapes in Russia. In: van Bynen PE (ed) Karst Management. Springer Netherlands, Dordrecht, 75-102.

Upchurch, S. B., \& Lawrence, F. M. (1984). Impact of groundwater chemistry along a retreating scarp. In Karst Hydrogeology: Engineering and Environmental Applications, Beck B.F and Wilson, W.L (eds), Rotterdam, A. A. Balkema, pp. 189-195.

Upchurch, S. B., \& Littlefield, Jr. (1988). Evolution of data for sinkhole-development risk models. Environ Geol Water Sci., 12(2), 135-140. https://doi.org/10.1007/BF02574800

Waltham, A. C., \& Fookes, P. G. (2003). Engineering classification of karst ground conditions. Quart J. Eng Geol Hydrogeol, 36, 101-118. https://doi.org/10.1144/1470-9236/2002-33

Williams, L. J., \& Kuniansky, E. L. (2015) Revised hydrogeologic framework of the Floridan Aquifer System in Florida and parts of Georgia, and South Carolina. Professional Paper 1807, U.S. Geological Survey, Reston, VA. https://doi.org/10.3133/pp1807

Zini, L, Calligaris, C., \& Franco, C. (2015). The challenge of tunneling through Mediterranean karst aquifers: The case study of Trieste (Italy). Environ. Earth Sci., 74, 281-295. https://doi.org/10.1007/s12665-015-4165-5

\section{Copyrights}

Copyright for this article is retained by the author(s), with first publication rights granted to the journal.

This is an open-access article distributed under the terms and conditions of the Creative Commons Attribution license (http://creativecommons.org/licenses/by/4.0/). 